Годишњак Филозофског факултета у Новом Саду, Књига ХХХVII (2012)

Борис Стојковски

Филозофски факултет Универзитета у Новом Саду

stbs@ptt.rs
УДК 929:2353(497.11 Sirmium)

Оригиналан научни рад

\title{
СВЕТИТЕЉИ БЕЗ ЖИТИЈА. ПРИНОСИ СИРМИЈСКОЈ ХАГИОГРАФИЈИ ${ }^{1}$
}

У раду се разматрају помени готово непознатих сирмијских светитеља које помињу извори, посебно боландистичка Acta Sanctorum и поједини мартиролози. Постоји и неколико светитеља чији помени и житија уносе забуну у хагиографију и на овом месту се покушавају разрешити те дилеме. О многима знамо углавном само име и датум спомена, и тек упоредном анализом више извора може се доћи до неког закључка о томе ко су ови свеци заиста и били. За велики број, пак, не постоје скоро никакве индиције ко су били.

Кључне речи: Сирмијум, мученици, хагиографија

Стари је Сирмијум био један од најзначајнијих хришћанских градова. На хагиогеографској карти света, почетком IV столећа, а у доба највећег и најсуровијег прогона хришћана, управо су многи пострадали у овом славном панонском граду. Најпознатији и највећи међу њима био је сирмијски ђакон Димитрије, који је временом постао у хагиографији ратник, конзул, високи достојанственик који је заштитник Солуна и чији је култ међу најраспрострањенијим у целом хришћанском свету.

Одмах уз њега је и Света Анастасија, чији се култ из Сирмијума преселио у Рим и где је и данас веома поштован међу верницима. Ту је свакако и баштован, који је пострадао као мученик, по имену Свети Синерот, као и Свети Иринеј, иначе први историјски документовани епископ Сирмијума.

Поред њих, о којима постоје и разне верзије њихових пасија, односно

1 Рад представља фазни резултат истраживања на два пројекта: први Војвођански простор y контексту европске историје (бр. 177002), који је финансиран од стране Министарства просвете и науке Владе Републике Србије и Средњовековна насеља на тлу Војводине. Историјски процеси и догађаји, бр. Решења 114-451-2216/2011, који финансира Покрајински секретаријат за науку Владе Аутономне покрајине Војводине. 
житија, помињу се у изворима и бројни сирмијски светитељи, махом мученици, о којима не знамо готово ништа. Зато смо их и назвали светитељи без житија. У наредним редовима покушаћемо да реконструишемо макар неке делове њихових претпостављених живота и страдања или макар да утврдимо јесу ли они на неки начин везани за Сирмијум.

Најважнији извори за нашу тему јесу Acta Sanctorum која су од 1643, па наредних неколико деценија, објављивали боландисти, односно, Société des Bollandistes који носе име по свом оснивачу Жану Боланду. Боланд, Иполит Делај и други аутори који су махом припадали језуитском реду, очеви су критичке хагиографије и дали су немерљив допринос критичком проучавању светачких легенди током претходних више од четрири столећа (Godding et al. 2007; Ван Омеслеге 2008: 210-221; Godding et al. 2009).

Поред 68 томова житија светих које су објавили боландисти у поменутој едицији за изучавање ових готово непознатих сирмијских светаца, важна су и два мартиролога, од којих је за један такође заслужно друштво боландиста. Сиријски мартиролог је први, (назива се у оригиналу Breviarium Syriacum, seu Martyrologium Syriacum), настао је највероватније око 360, можда чак и 411, највероватније у Витинији код Никомедије. Martyrologium Hieronimyianum је други мартиролог, можда и значајнији. Овај мартиролог се приписује Хијерониму, односно Светом Јерониму, чувеном преводиоцу Библије на латински и једном од најученијих људи са почетка средњовековног раздобља. А важност оба мартиролога је превасходно у томе што су сачували податке везане за светитеље IV и V столећа (Breviarium Syriacum 1956; Aigrain 2000: 23-26). Што се тиче поузданости, и сиријски и хијеронимски мартиролог су хронолошки најближи и доста су поуздани за рани IV век, када су се десила готово сва страдања сирмијских мученика и светаца којима се бавимо (Leemans 2006: 73). Из ових дела смо махом црпли изворне податке о светитељима из Сирмијума, као и из других врела.

Постоје мишљења де је Срем дао преко 200, махом анонимних мученика, који су пострадали у доба прогона хришћана, посебно под императором Диоклецијаном (Петровић 1970: 5). Тешко је заиста утврдити тај број, али вероватно је ова цифра претерана. У до сада прегледаним изворима и литератури наишли смо на најпотпунији списак у једном старијем мађарском 
католичком лексикону под одредницом Pannonia. Треба одмах на почетку рећи да се на попису панонских мученика може наћи на низ непрецизности, неправилности, па чак и нетачности, али је добра полазна основа за поређење са изворним подацима јер је, као што је већ поменуто, ово најдетаљнији списак. Од грешака везаних за значајније свеце издвајамо да Синерота упорно називају Синкрет, и годину његовог страдања стављају у 307. И за Свету Анастасију приређивачи овог лексикона наводе низ нетачности. Међутим, један податак је посебно фантастичан. Наиме, на попису панонских мученика на првом месту у овом лексикону се спомиње најпознатији међу њима, Свети Димитрије из Сирмијума, којег је цар Максимин Тракс дао убити 236-237, по чему је ово јединствен податак у целој историографији о Светом Димитрију (Katolikus lexikon 1932: 485-486).

Даље се у овом лексикону наводе следећим редом следећи наводни сирмијски светитељи: 23. фебруар-Антигон, Рутул, Либије (са још 70 мученика укупно 73). Следећи је 26. марта Монтан из Сингидунума, презвитер, и жена му Максимина, умрла такође у Сирмијуму. Већ наредног дана 27. марта помиње се наводно Александар, војник и мученик у Панонији. Потом, под 9. априлом пет или седам девица из Сирмијума, а 15. маја се слави Тимотеј, чије је наводно место страдања такође Сирмијум. Следећи на листи панонских мученика се слави 4. јула и то је Саватија и још 30 у Сирмијуму мученика. Последњи на овој крајње непрецизној листи, је под 9. августом извесни Свети Рустик Сирмијски (Katolikus lexikon 1932: 485-486). Овај последњи је очигледна грешка, или превид у читању рукописа мартиролога. Наиме, тог дана се славе заиста неки свети Фирмо и Рустик, али мученици из Вероне. Међутим, један манускрипт заиста помиње Сирмијум, али се ради о евидентној забуни (Acta sanctorum Augusti: 414).

И за претходну групу мученика ствари нису сасвим јасне, мада је могуће да су мученици из Сирмијума. Уз Саватију (изгледа особу јеврејског порекла), вероватно 304, страдао је и неки Свети Иноћентије, и још 30 мученика. Ни хијеронимски мартиролог не даје неки одговор, јер се у његовом рукопису Epternacensis уместо Сирмијума наводи се неки Серен, могућно још један мученик. Постоје претпоставке да је из Сирмијума у Рим пренета заоставштина Светог Иноћентија (pignota). Али се у различитим коментарима 
и манускриптима ових извора нуде и решења да је уместо Сирмијума, у питању Смирна као место њиховог страдања (Acta sanctorum Novembris 1931: 86; Acta sanctorum Iuli 1969: 6; Jarak 1996: 280-281).

Страдање Светог Александра, наведено под датумом 27. март, доноси неке забуне у панонску хагиографију. Наиме, један војник по имену Александар, страдао је у Тракији и слави се 15. маја, а био је заштитник града Дризипре, између Хадријанопоља и Цариграда. Његову цркву и мошти спалили су Авари у време цара Маврикија, о чему пише и византијски историчар Теофилакт Симоката (Theophylacti Simocatta 1832: 297; Acta sanctorum Martiis 1968: 690691) Житије војника из Дризипаре је објављено и у Acta sanctorum Maii (1968: 197-201). Да ли је 27. марта страдао у Панонији заиста неки Александар? Врло је тешко рећи. Поједини мартиролози само наводе In Pannonia St. Alexandri martyris. Међутим, тенденција хагиографа јесте да је у питању просто уметање Паноније, и да то није једини случај такве врсте (Acta sanctorum Martiis 1968: 691; Ritig 1912: 40-43). За сада питање око овог Александра остаје нерешено, упркос постојању два помена двојице војника истог имена.

На исти дан пострадања ђакона Димитрија, помињу се In Sirmia Natalis $V$ Virginum, quarum nomina Deus scit. Исти текст, само његов један други манускрипт наводи et alibi Demetri, Hilari, Concessi, Mari, Firmionis, Fortunati et septem virginum canonicarum. Манускрипт Berensis наводи овако: In Sirmio natal VII virginum et alibi Demetri, diaconi, Herakli, Concessi, Mari, Syrmium, Fortunati, Donati et VII virginum canonicaru. Чињеница је да изнад њихових имена стоји In Sirmia (Acta sanctorum Novembris 1931: 41). Познати истраживач ране хришћанске историје Паноније Жак Зеје није веровао да су у питању светитељи из Сирмијума (Зелер 2005: 102). Да ли овде смемо поверовати у Codex Epternacensis и прихватити да се ради о неком Фирмију или Фирмиону? Ово име није непознато у хагиографији, постоје свеци са тим именом. Довољно је само погледати у први том боландистичке збирке AA SS Januaris (1965: LXVII) и наћи неколико светаца сличног имена.

Или можда да поклонимо своје поверење боландистима који нуде следећи одговор. Број девица решен је на следећи начин. Код Часног Беде постоји спомен под петим идама - V Idus. In Sirmio natale septem Virginum, quae in unum merverunt coronati, односно, код других писаца, In Sirmio, septem 
Virginum canonicarum, que dato simul pretio sanguinis, vitam mercate sunt aeternam. Он је уистину написао један мартиролог између 725-731, који је носио назив Martyrologium de nataliciis sanctorum martyrum diebus; in quo omnes, quos invenier potui, non solum qua die, verum etiam quo quo genere certaminis, vel sub quo iudice mundum vicerint, diligenter adnotare studui. Проблем је што ове девице Беда назива Reginswindae virginis. Али, у овом манускрипту Colocensis, Беда наводи и два епископа Јакова, једног већ познатог из Сирије, а другог у Сирмијуму. Ради се о очигледној грешци, што доводи у питање цео овај мартиролог, макар везано за Сирмијум (Bedae Venerabilis Opera omnia 1862: 976; Acta sanctorum Aprilis: 820-821). Да се ових седам девица требају сматрати сирмијским мученицама сматрао је још пре једног века и Светозар Ритиг (1911a: 369). Што се осталих тиче, Хиларије је наводно римски мученик, као и већина са списка, и њихове мошти почивају широм Европе. За ђакона Димитрија се наводи једно посве необично решење - он се смешта у оне сирмијске мученике, погубљене после Монтана. Наводи се чак да је Димитрије страдао са Полионом из Цибалије, с тим што се прави врло велика грешка па се говори о панонским мученицима Јевсевију епископу, Полиону и Цибалу, чиме се веродостојност и истинитост целе ове тезе и овог дела веома озбиљно доводи у питање.

Да ли је код девица у питању омашка јер се под петима идама помиње седам девица не знамо, али је врло вероватно да је спомен и пет и седам девица нека омашка и да их је највероватније и било седам и страдале су вероватно 304. године (Jarak 1996: 276).

Још компликованије је питање страдања Светог Тимотеја мученика 15. маја. Уз њега се, наиме, наводе и седам девица. Сви су сирмијски мученици. Уз њих, хијеронимски мартиролог помиње и мученике Александра (sic!), затим неког Дигна, као и Хотију или Хотиду. Један манускрипт Коцију (тј. Хотију) придодаје после Тимотеја и седам девица. Боландисти не нуде готово никакво решење само набрајају манускрипте (Acta sanctorum Novembris 1931: 61; Acta sanctorum Maii 1968: 455-456). Готово је немогуће разлучити ко су ови свеци, да ли су уопште и постојали или је само нека легенда у питању. Видели смо да је питање девица већ доста замршено, а овај спомен Александра упућује да је можда и овде дошло до преноса његовог култа из Сирмијума у Дризипару или обрнуто. Исто тако, могуће је да се речца alibi која се у хијеронимском 
мартирологу махом пише после Тимотеја а пре спомена девица односи на све друге изузев самог Тимотеја, који је можда једини аутентични мученик из Сирмијума. За њега и седам девица сведочанство даје и једно латинско четворојеванђеље са краја VI века. На маргинама поред одломка Мт, 16, 21 налази зе се кратка белешка in timothei et vii (virginum) (Gamber 1982: 80).

Језуита Габријел Сердахељи у свом делу Celebriorum Hungariae urbim celebriora. Historico-Geographice descripta et comprehensa. Pars prima. Pannonia veterem complexa штампаном у Трнави 1701. даје занимљив списак светаца из Сирмијума. Редом наводи Светог Максимијана, Светог Акутија, затим следе Свети Тимотеј, Свети Херист, Свети Артакс, Свети Витус, Свете Тобија и Еугенда који се славе 2. јануара. Монтан и Максима су пострадали, према овом попису, заједно са још 40 људи 26. марта. Затим следи помен извесног Сирена (готово сигурно Синерота), под 23. фебруаром, када је, 302, пострадао (Szerdahelyi 1701: 9).

Нашу пажњу овом приликом заокупиће прва група светаца, који се прослављају 2. јануара. Заиста се код боландиста јављају имена сремских мученика Светог Максимијана, Светог Акутија, као и њихове сабраће у коју улазе Свети Тимотеј, Свети Херист, Свети Артакс, Свети Витус, као и на концу две жене-Свете Тобија и Еугенда (Acta sanctorum Januaris 1965: 80). Ово се спомиње, дакле, у првом тому, који је изашао још 1643, где се позива на хијеронимски (односно један његов старији и непоуздани рукопис) и Усуардов мартиролог из 1521. године. Међутим, у новом издању хијеронимског мартиролога, којег су скоро два века доцније приредили сами боландисти, долази до ревидирања става. Готово сигурно ове свеце можемо избацити из пописа панонских мученика (Ritig 1911b: 250-251).

Сиријски мартиролог помиње под 20. јулом Секунда, кога под 15. даном истог месеца наводи и хијеронимски, што је и датум прихваћен у науци. Заједно са њим спомињу се Агрипин, Фортунат и Максим, Марцијал, као и Свети Јаков, први епископ Нисибиса у Сирији (манускрипте (Acta sanctorum Novembris 1931: 91; Jarak 1996: 281). Боландисти заиста потврђују мучеништво ове петорице, Sirmii natalis sanctorum Agrippini, Secundi, Maximi, Fortunati, Martialis (Acta sanctorum Iulii 1968: 28). Чувени мађарски археолог Тибор Нађ наводи мученике, по имену Секундус и Агрипин, за њих каже им је непознато 
време страдања, а прослављају се у календару 20. јуна, али нигде нисмо наишли на њихов помен под овим датумом (Nagy 1939: 60).

Мартиролози 20. августа спомињу и Василију, девицу, наводе је као Basillae virginis, а постоји и њен спомен девет дана касније у једном извору (Nagy 1939: 60; Зелер 2005: 102-103). О њој постоји још један податак, који долази из Сердахељијевог дела, где он каже ornavit Syrmium et S. Basilla Sirmiensis, quae ibidem vitae sanctae finem imposuit, quem sancti solent. Ово би се могло уклопити у њено помињано девичанство. Била је дакле нека девица, која је водила свети живот и вероватно пострадала у прогонима хришћана. После ње се наводи Свети мученик Димитрије, који је врло славан (Szerdahelyi 1701: 10). Да ли њих двоје стоје у некој корелацији, готово немогуће је рећи. Индикативно је да се Василија помиње пре Димитрија. Једна могућност, свакако стоји, да су пострадали исте године. Међутим, то би све било у домену нагађања, јер немамо никакве потврде о некој међусобној вези, или ма какву другу информацију о Василији, сем једне претпоставке. Мирослава Мирковић, наша угледна професорка и стручњак за Сирмијум у антици наводи да је Басилија, тј. Басила жена једног другог мученика-Секунда. Али мартиролози стављају размак од месец дана између њих двоје и називају је девицом. Са друге стране, хагиографија је препуна случајева чедних супружника који су се заклели на невиност и били предани вери. Могли су такви бити управо и Сирмијци Секунд и Василија, односно Басила (Мирковић 2000: 100).

Као мученик страдао је у Сирмијуму и свештеник из Сингидунума Монтан, и његова жена Максима. Бачени су у реку, могуће Саву или Босут. Постоје и претпоставке, на основу бројних мартиролога и других старијих извора, да је можда презвитер управо сирмијске цркве који је пострадао уз свог епископа Иринеја и ђакона Димитрија (Rhuinart 1713: 404; Acta sanctorum Novembris 1931: 36; Acta sanctorum Martiis 1968: 616-617; Nagy 1939: 57; Петровић 1970: 5; Mócsy 1974a: 162-163; Mócsy 1974b: 329-330; Jarak 1996: 270271). У вези са овим би требало рећи да се спомињу још два свеца. Фортунат и Донат су у питању, поштују се у југоисточној Панонији, а пасија им је написана крајем V или почетком VI века, под утицајем легенде о Светом Полиону, чтецу из Цибалије и мученику коју је пострадао у данашњим Винковцима. Касније се и у Аквилеји развила традиција Хермагоре (сингидунумског, тј. београдског 
мученика) и Фортуната (Acta sanctorum Iulii 1969: 249-257; Nagy 1939: 59). У вези са Хермагором, постоји један невероватан податак. Боландисти, не трепнувши, наводе да је Хермагору посветио сам апостол Марко и та је теза ушла и у аустријски мартиролог (De magno legendario austriaco 1898: 71)

Свети Фортунат и Донат су важни, уз помињане Светог Синерота и Свету Анастасију из још једног разлога. Наиме, они су светитељи чији су гробови постали места ходочашћа и око којих се развило хришћанско гробље у граду (Mócsy 1974a: 162-163; Mócsy 1974b: 329-330). Ово би свакако могло да буде главна потврда тези да су Фортунат и Донат, уз своје пратиоце уз које су пострадали, били сирмијски свеци. Око њиховог порекла постоје разнолике тезе. Жак Зеје сматра да је готово немогуће одредити одакле су ови свеци. Он сматра да је у питању преписивање, и да су Acta S. Donati плагијат страдања Светог Полиона, летора из Цибалије. Супротног је става Ритиг, који сматра да су аутори делали у исто време и да се ова ва страдања допуњују. У том случају, Хермоген, Донат, али и Фортунат, Венуст, Ромул и Силван, који се помињу уз Доната, јесу сирмијски свеци (тзв. Донатова група). Њихов култ је међутим, у Аквилеју, пренет, као и многи други, после пропасти Сирмијума, или уопште у време варварске власти. Наилазимо у неким делима и на помен Монтана и Максиме, свештеника из Сингидунума, који је побегао у Сирмијум, али је онде ухваћен и са супругом бачен у Саву. Ритиг сматра да је уз њега страдало и 40 мученика, што је изгледа потврђено и у новијој историографији, чему је посебан допринос дао словеначки стручњак Рајко Братож који убедљиво разлучује панонске и аквилејске мученике уз помоћ како Хијернимовог мартиролога, тако и једне северноиталијанске легенде о овим мученицима настале у V столећу. (Ritig 1911a: 353-361, 364-366; Bratož 1986: 32-144; Jarak 1996: 273-274; Jarak 2003: 61; Зелер 2005: 95-97).

Под 14. августом помиње се неки светитељ Урсицин из непознатог града Сибентума, у чијем имену се, према Владиславу Поповићу, може наслутити Сирмијум (Поповић 2003: 275). Вероватније је да је он рођен у Сибентуму, а да се суђење Урсикину/Урсицину одржало у Сирмијуму (Jarak 1996: 281-282). Његов је култ пренет највероватније из Илирика у Милано, можда посредством царског двора и временом је придодат групи миланских светитеља коју сачињавају Свети Гервазије, Протазије и Валерије (Delehaye 1902: 891-892; 
Delehaye 1912: 324).

Постоје спомени и неких потпуно непознатих мученика. Тако, рецимо, митровачки жупник Павле Милер је 80-их година претпрошлога столећа саставио листу мученика у Сирмијуму у којој се појављују и нека хагиографији непозната имена. Рецимо, под. 9. априлом спомиње се Концесо, 8. Јануара 305. Ратитес је наводно пострадао, у фебруару се спомињу Свети Другови, као и 72 мученика. Милерове белешке наводе у марту Модерата, док крајем марта видимо на овом попису и неке светитеље Квадрата, Теодосија, Емануила, Филета, Лидију, Мацедонија, Треопепидија, као и напосе Амфилохија и Хромиду. Овај попис мученика спомиње и следеће свете, наводно у Сирмијуму пострадале: Иноћентија, Севаста и Севастију у јулу, као и Марцијала истог месеца. У августу се спомиње неки Свети Лупио/Лупије, као и Прокол и Максим (Максимо). Тешко је заиста рећи одакле је Милер црпео податке о овим светитељима (Прица 2004: 28). Постоји и традиција да је Филет био сенатор, да је страдао са породицом, а да је Амфилохије био неки вођа (Pavić 1891: 8).

Оно што уноси додатну забуну у овај спис јесте помен рецимо Светих Флора и Лавра који беху каменоресци из Улпијане (Stojkovski 2011: 209-211). Поред тога, спомињу се и Свети Епенет, потом Свети Андроник, као и Свети Елеутерије, који су вероватно потпуно легендарни епископи Сирмијума. Од њих је прву двојицу поменутих традиција довела у везу са Светим апостолима Ретром и Павлом, што је вероватно потпуна легенда (Стојковски 2011: 58-63). С тим у вези посматрано, вероватно и на овом попису има доста легендарних личности или просто светитеља из локалне традиције. Могуће је сасвим да су о некима нестали изворни подаци, али се сачувала локална традиција.

Међу онима о којима немамо никакве податке су и прво поменути из мађарског католичког лексикона Антигон, Рутул, Либије. Али број од 73 мученика није непознат. У Литанијама сирмијских светаца, које је објавио сремски бискуп Ладислав де Киш Серењи, а које су изгледа биле главни извор за жупника Милера, помињу се 73 мученика, али нема имена Антигон, Рутул или Либије. Са друге стране, ту су Ромул и Лидија, тако да је можда дошло до неке забуне у читањима неких предложака или рукописа. Имена Концеса, Светих Другова, Квадрата, и већине оних које помиње велечасни Милер се нлазе и у литанијама. Ратигес се код Серењија изгледа наводи као Патитес. (Szórényi de 
Kis Szörény 1746: 246-249)

Мученика је у Сирмијуму у доба прогона хришћана итекако било, али хагиографија оставља пред нас многе нерешиве енигме. Очигледно је пропаст античког и раносредњовековног Сирмијума оставила трајне последице и по животе светаца. Свети Димитрије, Света Анастасија, можда и још неки, постали су у новим срединама светитељи са другачијим биографијама и легендама које су их изместиле из њиховог града. Различите традиције, извори, манускрипти, пописи светитеља нуде нам имена многих наводно пострадалих мученика у Сирмијуму. О већини њих не знамо апсолутно ништа, а поједина се имена сусрећу тек у понеким изворима или чак секундарној или терцијарној литератури. Велики значај Сирмијума у мартирологији и хагиографији оставио је и велике проблеме у анализирању историје страдања сирмијских мученика.

\section{ИЗВОРИ И ЛИТЕРАТУРА}

Aigrain René (2000). L’hagiographie. Ses sources, ses méthodes, son histoire. Paris: Bloud and Gay.

Acta sanctorum Januaris, tomus pimus (1965). Bruxelles: Société des Bollandistes.

Acta sanctorum Martiis, Tomus tertius (1968). Bruxelles: Société des Bollandistes.

Acta sanctorum Maii, Tomus tertius (1968). Bruxelles: Société des Bollandistes.

Acta sanctorum Iulii, Tomus tertius (1969). Bruxelles: Société des Bollandistes.

Acta sanctorum Augusti, tomus secundus (1970). Bruxelles: Société des Bollandistes.

Acta sanctorum Novembris, tomus secundus (1931). Bruxelles: Société des Bollandistes.

Bedae Venerabilis Opera omnia, pars IV . y: Patrologiae Latinae cursus completus vol. XCIV, accuravit J-P Migne. Paris: ed. J-P Migne. 
Bratož Rajko (1986). Krščanstvo v Ogleju in na vzhodnem vplivnem območju oglejske crkve od začetkov do nastopa verske svobode. Ljubljana: Filozofska fakulteta, Znanstveni inštitut.

Breviarium Syriacum, seu Martyrologium Syriacum saec. IV iuxta Cod. SM. Musaei Britannici Add. 12150 (1956). Ex syriaco in latinum transtulit, notisque atque introd. illustravit Bonaventura Mariani, Roma: Herder.

Ван Омеслеге, Флор (2008). Acta Sanctorum и Боландистичка методологија у изучавағу хагиографије. У: Сергеј Хакел (прир.) Византијски светитель. Београд: Православни богословски факултет, 210-221.

Gamber Klaus (1982). Die lateinische liturgischen Quellen Illyriens vom 4. Bis zum 6. Jahrhundert. Sirmium IV: 77-85.

Godding Robert et al. (2007). Bollandistes, saints et légendes. Quatre siècles de recherche hagiographique. Bruxelles: Société des Bollandistes.

Godding Robert et al. (2009). De Rosweyde aux Acta Sanctorum. La recherche hagiographique des Bollandistes à travers quatre siècles. Bruxelles: Société des Bollandistes.

Delehaye Hyppolite (1902). Synaxarium ecclesiae Constantinopolitanae. Bruxellis: Société des Bollandistes.

Delehaye Hippolyte (1912). Les origines du culte des martyrs. Bruxelles: Société des Bollandistes.

De magno legendario austriaco (1898). Analecta Bollandiana, vol. 17: 2497.

Зелер Жак (2005). Почеци хришћанства на Балкану. Подгорица: CID.

Jarak Mirja (1996). Martyres Pannoniae-The Chronological Positions of the Pannonian Martyrs in the Course of Diocletian's Persecutions. In: Rajko Bratož (hrsg. ) Westillyricum ond Nordostitalien in der spätrömischen Zeit. Ljubljana: Narodni Muzej.

Ladislaus Szórényi de Kis Szörény (1746). Vindiciae Sirmienses seu descriptio Sirmii cum suo episcopatu. Budae: Typis Veronicae Nottensteinin.

Leemans Johan (2006). The Cult of Mars in Late Antique Caesarea. Studia Patristica. Papers Presented at the Fourteenth International Conference on Patristic Studies held in Oxford 2003. Leuven-Paris-Dudley, MA: 71-76.

Мирковић Мирослава (2000). Централне балканске области у доба 
позног изарства. у: Историја српског народа I. Београд: Српска књижевна задруга.

Mócsy András (1974a). Pannonia a késői császárkorban. Budapest: Akadémiai.

Mócsy András (19746). Pannonia and Upper Moesia. A History of the Middle Danube Provinces of the Roman Empire. London and Boston: Routledge and Kegan Paul.

Nagy Tibor (1939). A Pannoniai kereszténység története a Római védőrendszer öszeomlásáig. Budapest: Királyi Magyar Pázmány Péter Tudományegyetem Érem- és Régiségtani Intézete.

Pavić Matija (1891). Arijanstvo u Panoniji sriemskoj. Đakovo: Tiskom biskupijske tiskare.

Петровић Душан К. (1970). Историја Епархије сремске. Сремски Карловци: Издање Епархије сремске.

Поповић Владислав (2003). Последњи епископ Сирмијума. У: Sirmium град изарева и мученика (сабрани радови о археологији и сторији Сирмијума). Сремска Митровица: Благо Сирмијума.

Прица Радомир (2004). Хришћански мученици у Сирмијуму, у: Sirmiuт и на небу и на земљи (1700 година од страдања хришћанских мученика). Сремска Митровица: Благо Сирмијума.

Ritig Svetozar (1911a). Martyrologij srijemsko-pannonske metropolije. Bogoslovska smotra vol. 2, br. 3: 248-268.

Ritig Svetozar (1911б). Martyrologij srijemsko-pannonske metropolije. Bogoslovska smotra vol. 2, br. 4:353-371.

Ritig Svetozar (1912). Martyrologij srijemsko-pannonske metropolije. Bogoslovska smotra vol. 3, br. 1: 40-52.

Rhuinart Theodor (1713). Acta primorum martyrum sincera et selecta. Amstelaedami: Ex officina wetsteniana.

Szerdahelyi Gábor (1701). Celebriorum Hungariae urbim celebriora. Historico-Geographice descripta et comprehensa. Pars prima. Pannonia veterem complexa. Tyrnaviae.

Stojkovski Boris (2011). Holy Stonecutters from the Territory of nowadays Serbia. in: Violeta Cvetkovska-ocokoljić (ed. ), $1^{\text {st }}$ international conference 
"Harmony of Nature and Spirituality in Stone,, Proceedings, Kragujevac: Stone Studio Association: 209-216.

Стојковски Борис (2011). О апостолском пореклу епископије Сирмијума. Споменица Историјског архива Срем 10: 55-64

Theophylacti Simocattae Historiarum libri octo (1832). rec. Immanuel Bekkerus, Bonnae: ex impensis M. Weberi.

Boris Stojkovski

\title{
SAINTS WITHOUT LIVES (VITAE). CONTRIBUTIONS TO THE SIRMIAN HAGIOGRAPHY
}

\begin{abstract}
summary
This paper discusses mentions of almost unknown Sirmian saints who are cited by sources, especially in the Acta Sanctorum by Bollandists and some martyrologia, mainly Martyrologium Hyeronimianum and Breviarum Syriacum, both deriving from $4^{\text {th }}$ century. There are several saints whose Lives (Vitae) bring confusion in hagiography (such as Alexander, Timotheus, Virgin Saints, Basilla, etc) and at this point, the author tends to try to resolve the dilemmas. On many of these saints we know mostly only their proposed name and date of their veneration or martyrdom, and only a comparative analysis of multiple sources can come to some conclusion as to who these saints really were. For many others, however, there are almost no indications of who they were or even did they exist.
\end{abstract}

